\title{
Uterine function in Meishan pigs
}

\author{
R. K. Christenson, J. L. Vallet, K. A. Leymaster and L. D. Young \\ US Department of Agriculture, Agricultural Research Service, Roman L. Hruska US Meat Animal \\ Research Center, PO Box 166, Clay Center, NE 68933-0166, USA
}

\begin{abstract}
The Meishan pig provides a biological model with the genetic capacity to express a high prolificacy. This prolificacy can be partially attributed to a higher ovulation rate and a higher rate of prenatal survival at a given ovulation rate throughout gestation than in European breeds. Both early embryonic survival (factors inherent to the ovum and uterus, which occur before day 25 of gestation) and uterine capacity (factors inherent to uterine limitation, which occur from 30 days of gestation to parturition) may contribute to prenatal survival. Crossbreeding studies show that the prolificacy of Meishan pigs is primarily of maternal origin, but not whether the effects occur via the ovum, uterus or systemic factors. Although there have been few comparative studies on uterine function for prolific pigs, experiments relating to three general areas have been reported. During neonatal uterine development, endometrial gland development occurs shortly after birth in Meishan and European breeds. Tissue culture for $24 \mathrm{~h}$ showed that secretion of at least three uterine proteins (one identified as retinol-binding protein) increased in clear temporal association with development of the endometrial gland. The secretion of two additional proteins appears to change in a breed-specific manner. Although regulatory roles for uterine proteins remain to be defined, biochemical events associated with neonatal endometrial gland development may affect subsequent adult uterine function. During the time of maternal recognition of pregnancy or early gestation, reports suggest that uterine secretions are enhanced in Meishan pigs, which may partially explain their increased prolificacy. However, other studies show smaller embryo and placental weights at day 30 of gestation, suggesting that prolificacy of Meishan females is related to a maternal ability to control embryo/fetal and placental growth. During the later fetal period (uterine capacity) in European pigs, endometrial response to a crowded uterine environment is minimal, but the conceptus responds to a crowded uterine environment by altering placental function; similar experiments using Meishan pigs are in progress. Once the regulatory determinants of uterine function are understood, improvements can possibly be made in the reproductive efficiency of all swine.
\end{abstract}

\section{Introduction}

Increasing the average number of piglets per litter in swine would increase efficiency of swine production and benefit almost everyone from swine producers to consumers. Litter size in swine is determined by ovulation rate, fertilization rate, early embryonic survival before day 25 and number of fetuses that the uterus can support (uterine capacity) from day 30 to term (Christenson et al., 1987; Bennett and Leymaster, 1989). Studies show that increasing the number of available ova/embryos by selection for increased ovulation rate (Cunningham et al., 1979; Johnson et al., 1984), by hormonal superovulation (Longenecker and Day, 1968; Christenson et al., 1973), or by embryo transfer (Dziuk, 1968; Fenton et al., 
1969) results in an increase in the number of embryos at day 30, but this advantage is lost during late gestation. Thus, the capacity of the uterus to carry an increased number of fetuses beyond day 30 of pregnancy represents a significant limitation on increases in litter size. A better understanding of factors controlling neonatal uterine development and uterine and placental function during pregnancy may improve litter size in swine.

The prolific Meishan pig (Cheng, 1983; Legault and Caritez, 1983; Zhang et al., 1983; Bolet et al., 1986; Yun, 1988) provides a useful model for the study of the influence of uterine function on litter size. A limited number of studies concerning uterine function in prolific breeds have been conducted since Meishan pigs were first imported to France, UK, Japan and the United States. This review will summarize information on the components of litter size in prolific Chinese Meishan pigs and describe current research relative to uterine development and function in pigs.

\section{Components of Litter Size in Pigs}

\section{Ovulation rate}

Ovulation rates for Meishan and European breeds of pig have not been in full agreement because comparisons have been made at different chronological ages using various European breeds. Comparison of Meishan and Large White gilts at puberty or third and fourth oestrous cycles has shown a greater ovulation rate in Large White than in Meishan females (Bolet et al., 1986; Bazer et al., 1988a, b). However, comparison of Meishan and Large White females of similar chronological age suggests that Meishan females shed a similar number of ova (Terqui et al., 1990) or more ova (Haley and Lee, 1990; Ashworth et al., 1992). Christenson (1993) compared ovulation rate at puberty and two chronological ages in Meishan and white crossbred gilts and reported that at puberty (118 and 217 days of age, respectively) ovulation rate was similar for Meishan (12.3 corpora lutea) and white crossbred gilts (12.7 corpora lutea). However, comparison at 220 and 280 days of age resulted in greater $(P<0.01)$ ovulation rates in Meishan than in white crossbred gilts ( $16.7 \pm 0.5$ versus $12.7 \pm 0.4$ corpora lutea at 220 days of age and $16.5 \pm 0.7$ versus $13.9 \pm 0.6$ corpora lutea at 280 days of age respectively). More importantly, the pattern of change in ovulation rate differed for Meishan and white crossbred gilts (Fig. 1). In Meishan gilts, ovulation rate increased $(P<0.01) 4.3$ corpora lutea from puberty to the sixth $(220$ days of age) oestrous period and was relatively constant from the sixth to the ninth ( 280 days of age) oestrous period. Although the number of corpora lutea in white crossbred gilts increased by 1.2 corpora lutea from puberty ( 217 days of age) to the fourth ( 280 days of age) oestrous period, this increase in ovulation rate was not significant $(P>0.05)$.

Bolet $e t$ al. (1986) reported that ovulation rate in Meishan gilts increased significantly between the first $(9.2 \pm 0.8$ corpora lutea) and third (11.7 \pm 0.6 corpora lutea) oestrus, whereas there was no comparable increase from first (13.7 \pm 0.7 corpora lutea) to third (14.4 \pm 0.6 corpora lutea) oestrus in Large White gilts. A number of studies with European breeds of pig (Robertson et al., 1951; Warnick et al., 1951; Paterson and Lindsay, 1980; Kunavongkrit and Larsson, 1982) have shown that ovulation rate increases after puberty with successive oestrous periods. Kirkwood and Aherne (1985) concluded that ovulation rate in gilts reaching puberty at young ages (5-7 months) will increase with each oestrous period. However, in older gilts ( $>8$ months), ovulation rate increases with successive oestrous periods are greatly reduced (Dyck, 1971). It is not therefore surprising that early maturing Meishan gilts show an increase in ovulation rate after puberty. In addition, this substantial increase in ovulation rate from puberty to the sixth oestrous period in Meishan gilts may help to explain why ovulation rate comparisons between Meishan and European breeds of gilt have varied from study to study. The high ovulation rate in Meishan gilts has also been observed in Meishan sows. Christenson (1993) reported that ovulation rates were greater $(P<0.01)$ for Meishan than for white crossbred sows at 417,608 and 735 days of age, which represents first, second and third parity (Fig. 1). This is in agreement with reports by Haley and Lee (1990) and Anderson et al. (1993). Whereas ovulation rate appears to increase with age for Meishan sows, ovulation rate increases only slightly with age in white crossbred sows. Thus, the greater prolificacy of Meishan females is, in part, the result of high ovulation rates. 


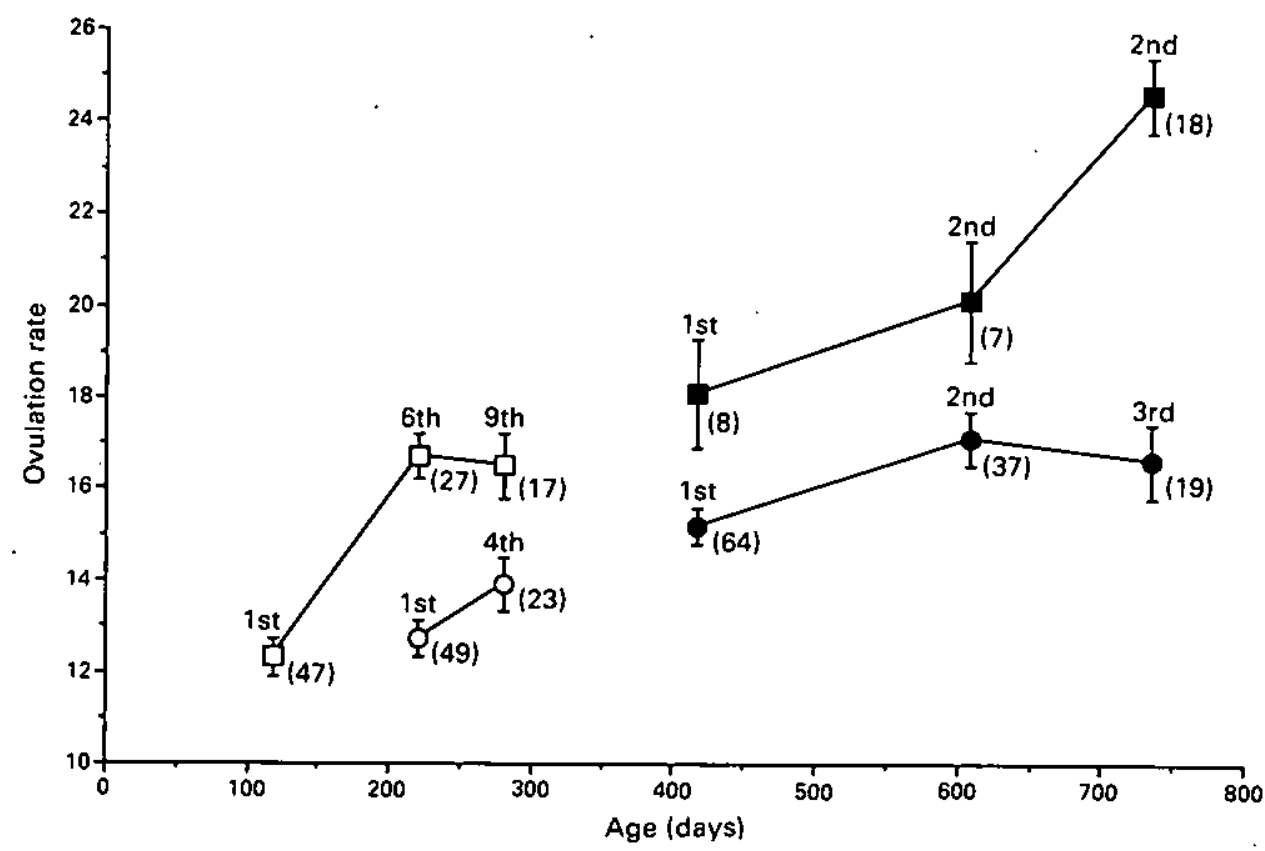

Fig. 1. Ovulation rate at first (puberty), sixth, and ninth oestrous period for ( $\square$ ) Meishan and first (puberty) and fourth oestrous period for $(O)$ white crossbred gilts and at three ages (first, second and third parity) for ( $\square$ ) Meishan and ( $)$ white crossbred sows. Numbers of gilts or sows are given in parentheses. Age at puberty was earlier $(P<0.01)$ for Meishan than for crossbred gilts, but ovulation rate at puberty was similar. Breed comparison (mean \pm SEM) of ovulation rate at 220 and 280 days of age for gilts and at 417,608 , and 735 days of age for sows were significantly different $(P<0.01)$. (Adapted from Christenson, 1993.)

\section{Fertilization rate}

Fertilization is one of the essential components of the sequential reproductive events that lead to the production of offspring in pigs but with appropriate reproductive management, it is a component that has little influence on litter size. Natural mating under optimal conditions in which sows are mated twice during oestrus usually results in very high fertilization rates, and examination of ova shortly after mating shows that fertilization occurs in 95\% of the females (Hancock, 1958; Thibault, 1959; Perry and Rowlands, 1962). Furthermore, the percentage of ova that are fertilized in individual animals is near $100 \%$ in most sows (Perry, 1960). Limited information is available on the fertilization rate of Meishan and other Taihu pigs.

\section{Embryonic survival}

Rates of embryonic survival have been examined at various stages after mating in Meishan and European gilts and sows (Fig. 2). In our laboratory, studies comparing conceptus development and morphological diversity at days 11-12 of gestation indicated that conceptus recovery and survival at slaughter was $95 \%$ in both Meishan and composite white crossbred sows (Anderson et al., 1993). Galvin et al. (1991) reported that embryonic survival rates were 82 and $73 \%$ at $20-22$ days of gestation in Meishan and Large White sows, respectively. At 30 days of gestation, several investigators have reported greater $(P<0.01)$ embryonic survival rates for Meishan than for Large White gilts (Bazer $e$ al., 1988b; Terqui et al., 1990). In contrast, several investigators have reported no statistically significant difference in embryonic survival rates, although embryonic survival was sometimes greater ( 80 versus $72 \%$; Ashworth et al., 1992) or smaller (73 versus $81 \%$; Christenson, 1993) for Meishan than for white crossbred gilts, respectively. Thus, embryonic survival rates are at least equal or greater for Meishan than 


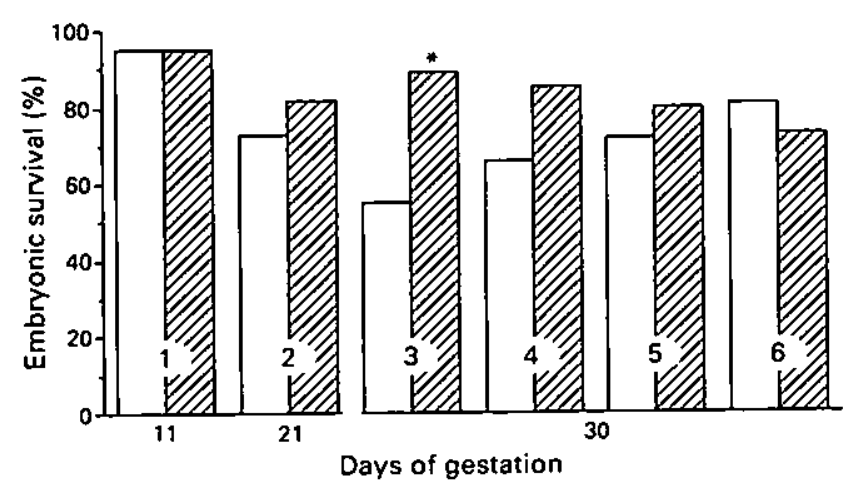

Fig. 2. Percentage embryonic survival at 11,21 and 30 days of gestation in ( $\square$ ) European and ( $\square$ ) Meishan gilts and sows. "Within study, breed means for embryonic survival are significantly different $(P<0.01$ ). (Adapted from 1 - Anderson et al., 1993; 2 Galvin et al., 1991; 3 - Bazer et al., 1988b; 4 - Terqui et al., 1990; 5 - Ashworth et al., 1992; and 6-Christenson, 1993.)

for European females. Increased ovulation rates coupled with equal or greater early embryonic survival combine to have a positive influence on the prolificacy of Meishan pigs.

\section{Uterine capacity}

Litter size has changed little in European breeds of pig since 1921 when Sir John Hammond first discussed the relationship between ovulation rate, embryonic mortality, uterine environment, and number of pigs born. In the intervening years, numerous studies have shown that increasing the number of ova/ embryos by direct selection for increased ovulation rate (Cunningham et al., 1979; Johnson et al., 1984), by hormonal superovulation (see review by Anderson and Melampy, 1972), or by embryo transfer (Dziuk, 1968; Fenton et al., 1969) results in an increase in the number of embryos on day 30 of gestation. However, litter size at farrowing was not significantly increased, which suggests that uterine environment after day 30 is limiting to increased litter size. This concept of uterine environment limiting litter size is further supported by experimental evidence (Fig. 3) indicating that litter size at birth approaches a plateau as ovulation rate increases (Leymaster et al., 1986; Christenson et al., 1987). This uterine limitation, hereafter termed uterine capacity, has been defined as the maximum number of fetuses that can be maintained to term when the number of potential viable embryos is not a constraint (Christenson $e t$ al., 1987). Bradford (1972) emphasized the need for an objective measure of uterine capacity. The uterus must be challenged with more embryos than can be maintained to parturition to obtain such a measure. The expression of uterine capacity occurs when fetuses in excess of the uterine capacity of each gilt die before parturition. Leymaster et al. (1986) and Christenson et al. $(1987,1988)$ established that the number of fully formed pigs (litter size) of unilat erally hysterectomized-ovariectomized (UHO) gilts is a physiologically valid method for measuring uterine capacity per uterine horn in individual gilts. UHO results in compensatory ovarian hypertrophy of the remaining ovary (Brinkley et al., 1964; Dziuk, 1968), but does not appear to result in uterine hypertrophy of the remaining uterine horn (Leymaster et al., 1986; Christenson et al., 1988). Thus, the UHO model doubles the number of ova or potential embryos per uterine horn and provides the opportunity to study effects of uterine capacity on fetal mortality and on litter size at birth. to identify physiological factors affecting uterine capacity, and to determine the heritability of uterine capacity.

Bennett and Leymaster (1989) hypothesized that prenatal mortality occurs in two phases resulting from distinctly different mechanisms. In the first phase, ovulation rate is reduced to the number of potentially viable embryos by factors inherent to the ovum/embryo, and this phase is independent of uterine capacity. Causes of this reduction include ovulation of primary oocytes, fertilization failure, polyspermy, chromosomal aberrations and abnormal blastocyst development. These reductions occur 


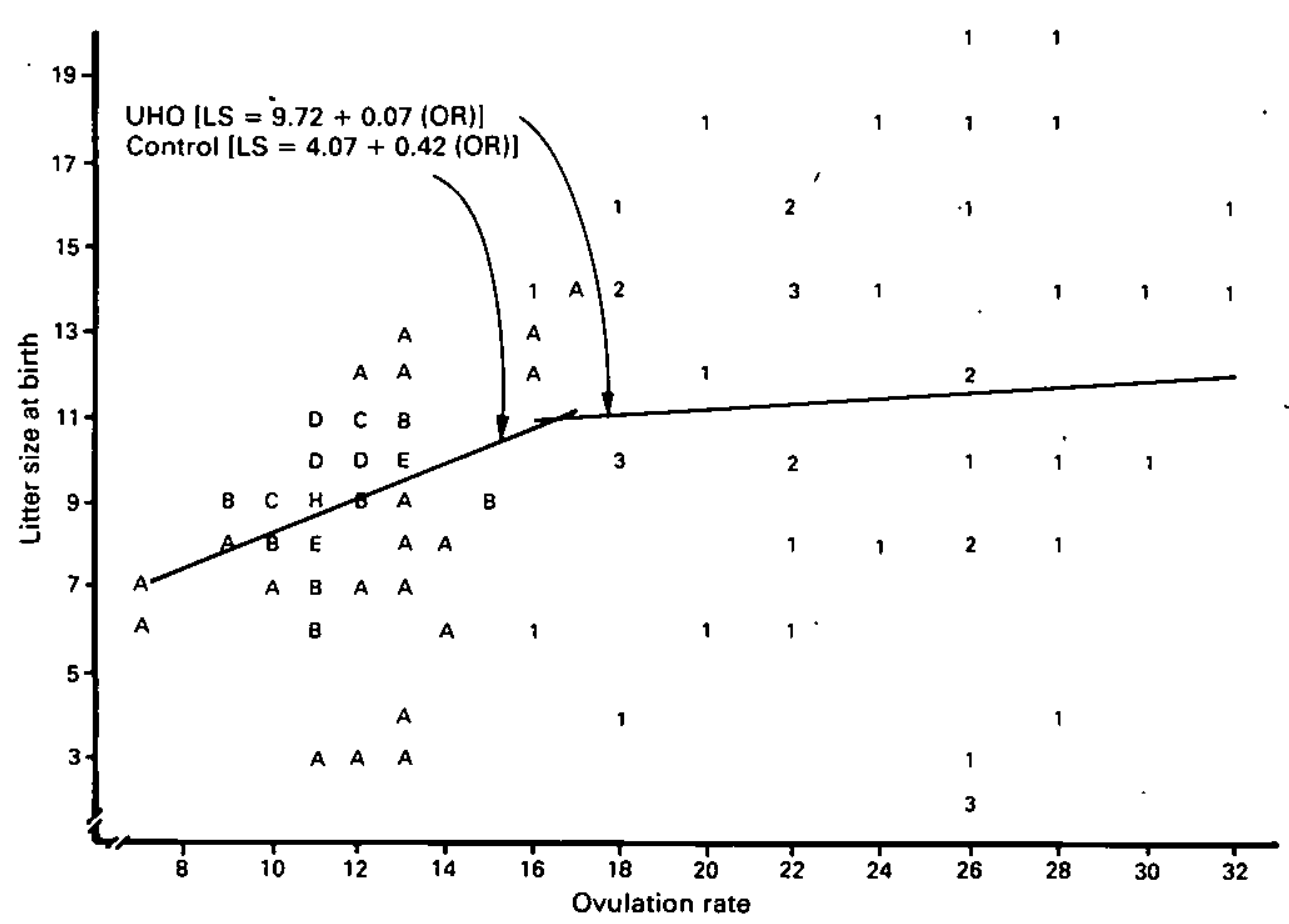

Fig. 3. Relationship between litter size (LS) at birth and ovulation rate (OR) for control and unilaterally hysterectomized-ovariectomized (UHO) white crossbred gilts. Ovulation rate and litter size data collected on UHO gilts were multiplied by two to represent a bivariate distribution on a total uterine basis. Letters (control) and numbers (UHO) in the graph represent the number of litters (for example $A=1, B=2$ and $1=1,2=2$ ) observed. (Adapted from Christenson et al., 1987.)

before day 20-25 of gestation (Hunter, 1966; Wrathall, 1971; Scofield, 1972; Flint et al., 1982; Koenig et al., 1986). Such factors are considered inherent to the ovum/embryo and are not directly associated with limitations of the maternal uterine environment (Dziuk, 1968; Longenecker and Day, 1968; Fenton ef al., 1970; Pope et al., 1972; Webel and Dziuk, 1974; Knight et al., 1977). The probability of survival during this phase is called potential embryonic viability.

The second phase of prenatal mortality occurs only when the number of potential viable embryos present at 25-30 days of gestation exceeds uterine capacity. This reduction is a consequence of competition among embryos/fetuses for limited maternal resources (Longenecker and Day, 1968; Bazer et al., 1969; Fenton et al., 1970; Webel and Dziuk, 1974; Knight et al., 1977; Christenson et al., 1987). Consequently, the uterine capacity of each female interacts with ovulation rate and potential embryonic viability to determine prenatal mortality and litter size.

Using Meishan, Large White, and reciprocal crossbred gilts, Haley and Lee (1990) reported that Meishan and reciprocal-crossbred gilts had a $20 \%$ greater prenatal survival to parturition than that of Large White gilts at any given ovulation rate. Similarly, L. D. Young (unpublished observations) has found a $17 \%$ advantage in prenatal survival to day 100 of gestation for Meishan $F_{1}$ crossbred versus Duroc $F_{1}$ crossbred gilts. This genetic expectation is one-half of the genetic expectation reported by Haley and Lee (1990). These experiments combined suggest that Meishan pigs have a $20-34 \%$ advantage relative to Duroc and Large White pigs in prenatal survival at any given ovulation rate over the range of ovulation rates for these breeds. If prenatal survival throughout gestation is greater in Meishan gilts as a result of reduced prenatal mortality, what factor(s) contributes to this increased prenatal survival? Bazer et al. (1988b) suggested that the increased prenatal survival of the Meishan female may result from an increased uniformity of embryonic development. However, Wilmut et al. (1992) and Anderson et al. (1993) found no difference in within litter variation of embryonic development for Meishan and European gilts and sows before day 12 of gestation. In addition. Ashworth et al. (1992) found no evidence 
of greater uniformity among littermate Meishan fetuses than among littermate Landrace $\times$ Large White fetuses between 27 and 31 days after mating. It is, therefore, unlikely that greater uniformity of embryonic development provides an adequate explanation for the increased prolificacy of Meishan pigs.

Evaluation of embryonic development data at day 30 of gestation for Meishan and European gilts yielded more consistent data than did evaluations earlier in gestation. Bazer et al. (1988b) reported no difference in embryonic weight and embryonic length at day 30 of gestation for Meishan and Large White gilts, but did report smaller placental weights and allantoic fluid volumes for Meishan than for Large White gilts. Ashworth et al. (1992) and Christenson (1993) reported smaller embryonic weights and lengths, placental weights (not reported by Ashworth et al., 1992), and allantoic fluid volumes at day 30 of gestation for Meishan than for white crossbred gilts. The observation that fetal size differences are largely controlled by the maternal genotype (Ashworth et al., 1990) is apparent as early as day 30 of pregnancy. This lends support to the hypothesis that a contributing factor to Meishan prolificacy is a maternal ability to control embryonic/fetal and placental growth, thus possibly reducing fetal competition and effectively increasing uterine capacity.

The above results using Meishan pigs suggest that uterine capacity has a genetic component, and evidence of intra-line genetic variation of uterine capacity has recently been reported for mice (Kirby and Nielsen, 1993) and pigs (Gama and Johnson, 1993). In addition, direct comparison of uterine capacity of Meishan and European breeds of pig using the UHO gilt shows that Meishan pigs have a greater uterine capacity (Haley and Lee, this supplement). Pigs selected for uterine capacity or which already possess increased uterine capacity (i.e. Meishan pigs) may prove useful for increasing litter size and determining other physiological factors and the biochemical basis of uterine capacity.

\section{Uterine Development}

Neonatal uterine growth and development may influence subsequent adult uterine function and have a significant effect on prenatal survival during early gestation (maternal recognition of pregnancy) and during the later fetal period (uterine capacity). Neonatal uterine development has been described grossly (Dyck and Swierstra, 1983; Wu and Dziuk, 1988) and histologically (Hadek and Getty, 1959; Bal and Getty, 1970; Erices and Schnurrbusch, 1979) in European pigs from birth to puberty. Neonatal porcine uterine growth, as measured by uterine horn length and weight, develops in an ovary-independent mode before day 60 of neonatal life ( $W u$ and Dziuk, 1988). During this period, the porcine uterine wall undergoes dramatic remodelling events including appearance and proliferation of endometrial glands, formation of endometrial folds, and growth and development of the myometrium (Hadek and Getty, 1959; Bal and Getty, 1970; Erices and Schnurrbusch, 1979; Dyck and Swierstra, 1983). A variety of morphological events and biochemical factors are involved in the early development of the uterus of neonatal pigs and these have been reviewed by Bartol et al. (this supplement).

Although numerous studies have been conducted in European pigs, only Miyano et al. (1990a, b) and Christenson et al. (1992) have compared ovarian and uterine development in neonatal Meishan and European breeds of gilt. In general, morphological uterine development (uterine weight and length, endometrial and myometrial thickness) from 1 to 45 days of age was similar for Meishan and European breeds of gilt. Marked increases in ovarian and uterine horn weight, endometrial, circular and longitudjnal myometrial thickness (or cross-sectional area) were observed by day 60 in Meishan and by 90-100 days of age in European breeds of gilt. These increases are probably due to the first appearance of ovarian vesicular follicles in Meishan (about 45 days of age) and in European (about 70 days of age) gilts. Using histological evaluation, Miyano et al. (1990a) observed uterine gland differentiation on day 1 of age in two of two Meishan and zero of two Landrace gilts. Christenson et al. (1992) found evidence of uterine gland differentiation in one of four Meishan and in one of seven white crossbred gilts on day 1 of age. At 14 days of age, all Meishan and white crossbred gilts had uterine glands, and gland development increased steadily in both breeds through 42 days of age (Christenson et al., 1992). After ovarian vesicular follicle appearance at approximately 45 days of age in Meishan gilts (Miyano et al., 1990b), a marked increase in uterine gland development was observed by 60 days of age and, although not determined, a similar increase is expected in European breeds by 90-100 days of age. In addition to histological evaluation. Christenson et al. (1992) cultured tissue obtained from Meishan and white crossbred gilts on day 1 , 
$14,28,42$ or 56 . Culture for $24 \mathrm{~h}$ in the presence of $\left[{ }^{3} \mathrm{H}\right]$ leucine followed by two-dimensional polyacrylamide gel electrophoresis (2D-PAGE) and fluorography were used to identify $\left[{ }^{3} \mathrm{H}\right]$ leucine-labelled proteins secreted by neonatal uterine tissue during uterine gland development. For both breeds, secretion of at least three proteins increased in clear temporal association with uterine gland development (Christenson et al., 1992), including one $\left(M_{\mathrm{r}} \times 10^{-3} / \mathrm{pJ} ; 20 / 5.5\right)$ that crossreacts with antiserum to retinol-binding protein (Vallet et al., 1992). In addition, production of one protein (97/4.0) increased by day 28 in Meishan but not in white crossbred gilts, whereas production of another protein (13/6.0) increased in white crossbred but not in Meishan gilts by 56 days of age. Although specific regulatory roles for locally produced uterine proteins remain to be defined, the observation that biochemical events associated with neonatal endometrial gland development may differ between a recognized prolific and a European breed of pig supports the idea that these events may affect subsequent adult uterine function.

\section{Uterine and Placental Function}

The mechanism by which the uterus and placenta interact to accomplish their respective roles during gestation in swine has been studied for years. Information is available on several aspects of both uterine and placental function, and reviews summarizing this information are available (Davis, this supplement; Roberts, this supplement). In this section, only a brief summary of this information will therefore be presented.

The endometrium secretes nutrients in the form of histotroph. Proteins that are known or suggested to transport nutrients to the developing conceptus include uteroferrin (Roberts and Bazer, 1980) and retinol-binding protein (Roberts and Bazer, 1988). These proteins are secreted by the glands of the endometrium predominantly in response to progesterone (Chen et al., 1975; Adams et al., 1981). In fact, Basha et al. (1979) reported that the cohort of endometrial proteins secreted during pregnancy is controlled by progesterone, whereas the presence of the conceptus influences only the rate of secretion of the progesterone-induced proteins. Oestrogen in combination with progesterone increases endometrial secretion of uteroferrin (Roberts and Bazer, 1980), retinol-binding protein (Trout et al., 1992), and total luminal protein in general (Knight et al., 1974). The effects of progesterone and oestrogen on secretion of uteroferrin and retinol-binding protein appear to be mediated at least in part by increases in mRNA (Simmen et al., 1991; Trout et al., 1992). It is well established that the pig conceptus secretes oestrogen at several stages during development. Secretion of oestrogen by the conceptus occurs between days 11 and 15 and is thought to be part of the signal for maternal recognition of pregnancy (Bazer and Thatcher, 1977). This period coincides with increased secretion of histotroph from the endometrium (Geisert et al., 1982). Oestrogen secretion falls and then rises again to a peak at day 30 of gestation (Robertson and King, 1974). This rise in oestrogen occurs coincidentally with a peak in allantoic fluid volume (Knight et al., 1977) and an increase in endometrial retinol-binding protein mRNA (Trout et al., 1991). Oestrogen secretion by the conceptus falls to a nadir at about day 40 of pregnancy and then increases again gradually to a peak at term (Robertson and King, 1974).

The uptake of uteroferrin by the pig placenta provides a model for the mechanism by which the placenta absorbs histotroph proteins. Electron microscope studies indicate that the placenta takes up uteroferrin by fluid phase pinocytosis and transfers it to the fetal circulation (Raub et al., 1985). The liver then absorbs uteroferrin from the fetal circulation (Saunders et al., 1985). Uteroferrin, which is not cleared by the liver, is secreted into the allantoic sac where mechanisms exist to recover the iron and return it to the fetus (Buhi et al., 1982). The allantoic sac provides a reservoir for excess proteins of endometrial origin and this is reflected by the amounts of secreted endometrial proteins found in allantoic fluid (Buhi et al., 1983). Little information regarding factors (including fetal factors) that influence the efficiency of uptake or utilization of nutrients by the placenta is available.

Because the Meishan pig has better prenatal survival than other breeds, it provides a useful model to examine the influence of uterine and placental function during the time of maternal recognition of pregnancy in prolific Meishan and European breeds of pig. Bazer et al. (1991) reported that the uterus of Meishan pigs secretes more total protein, immunoglobulin $A$ and $G$, acylaminopeptidase, glucose, fructose and prostaglandin $\mathrm{E}$ and $\mathrm{F}_{2 \alpha^{\prime}}$ and less acid phosphatase at day 14 of pregnancy than do Large White pigs. Simmen et al. (1989) reported differences in the presence of insulin-like growth factor I (IGF-I) 


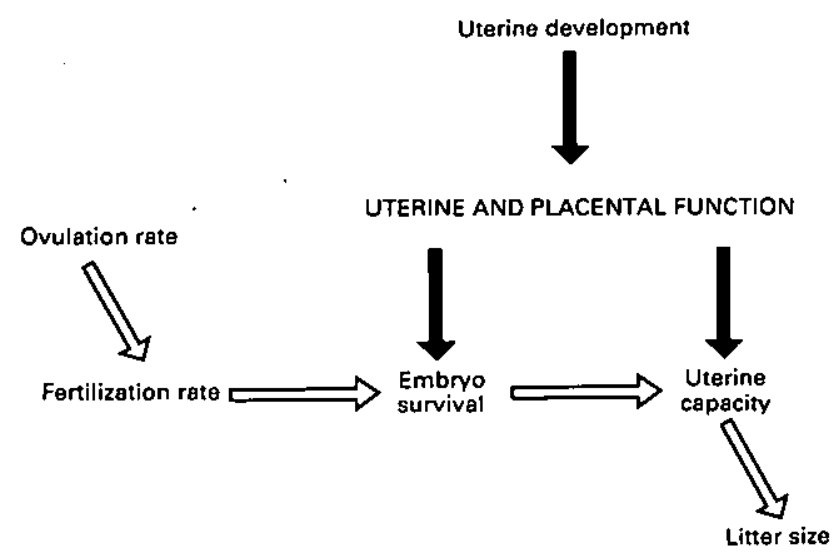

Fig. 4. Relationship of the component traits of litter size, uterine development, and uterine and placental function in pigs.

and uterine luminal mitogen between Meishan and Large White breeds. They reported that the temporal pattern of IGF-I concentrations was altered during the time of matemal recognition of pregnancy in Meishan versus Large White pigs with the peak of IGF-I concentrations occurring later in Meishan pigs. There was also a trend for Large White pigs to have higher concentrations of the uterine luminal mitogen than do Meishan pigs. Taken together, these data suggest that uterine function in Meishan pigs may be enhanced compared with European breeds, and may partially explain their increased prolificacy.

Although the experiments summarized above have yielded information on several of the functions performed by the uterus and placenta during pregnancy in pigs, few studies have attempted to link the known biochemistry of the uterus and placenta to the later fetal period (uterine capacity). Studies in which uterine capacity has been exceeded have shown that under crowded uterine conditions, significant fetal loss occurs between day 30 and day 45 of pregnancy (Knight et al., 1977; Chen and Dziuk, 1993). Although the biochemical basis for the death of the fetuses during this period has not been studied, some suggested mechanisms may be hypoxia, waste accumulation or lack of some essential nutrient. The sensitivity of fetuses during this critical period suggests that studying uterine and placental factors during this period may be useful in elucidating the specific causes of fetal loss under crowded uterine conditions. Vallet and Christenson (1993) studied endometrial and placental protein secretion in white crossbred gilts in which crowded and uncrowded uterine environments were created by ligating one uterine hom 4 days after mating. Endometrial and placental protein secretion was examined by culturing tissue obtained on days 25 and 35 of gestation and then subjecting the culture medium to 2D-PAGE and fuorography. On both days, placental and fetal weights were smaller in the crowded than in the uncrowded uterine environment. Results showed that the secretions of four placental proteins were changed when uterine space per conceptus was altered, whereas protein secretion and $\left[{ }^{3} \mathrm{H}\right]$ thymidine incorporation by the endometrium were not changed. Endometrial adaptation to crowding may therefore be limited, and the conceptus may respond to decreased uterine space by alterations in placental function. Similar comparative studies have not been completed in Meishan and white crossbred gilts.

\section{Conclusion}

Studies of the components of litter size in Meishan and European breeds of swine have suggested mechanisms that may contribute to the prolificacy of Meishan pigs. Evidence suggests that Meishan pigs differ in neonatal uterine development and in uterine and placental function during gestation. The influence of uterine development and uterine and placental function is, therefore, important in our concept of litter size in swine (Fig. 4).

The authors thank the Swine Operations Staff for assistance with management of pigs, D. Sypherd for technical assistance, and $\mathrm{L}$. Pamell for assistance in preparing this manuscript. 


\section{References}

Adams KL, Bazer FW and Roberts RM (1981) Progesteroneinduced secretion of a retinol-binding protein in the pig utenus joumal of Reproduction and Fertility 62 39-47

Anderson LH, Christenson LK, Christenson RK and Ford SP (1993) Investigations into the control of litter size in swine: II. Comparisons of morphological and functional embryonic diversity between Chinese and American breeds joumal of Animal Science 71 1566-1571

Anderson L.L and Melampy RM (1972) Factors affecting ovulation rate in the pig. In Pig Production pp 329-366 Ed. DJA Cole. Butterworths, London

Ashworth CJ, Haley CS. Aitken RP and Wilmut I (1990) Embryo survival and conceptus growth after reciprocal embryo transfer between Chinese Meishan and Landrace $\times$ Large White gilts Jounal of Reproduction and Fertility 90 595603

Ashworth CJ, Haley CS and Wilmut I (1992) Effect of Regumate on ovulation rate, embryo survival and conceptus growth in Meishan and Landrace $\times$ Large White gilts Theriogenology 37 433-443

Bal HS and Getty R (1970) Postnatal growth of the swine uterus from birth to six months Growth 34 15-30

Basha SMM. Bazer FW and Roberts RM (1979) The secretion of a uterine specific, purple phosphatase by cultured explants of porcine endometrium: dependency upon the state of pregnancy of the donor animal Biology of Reproduction 20 $431-441$

Bazer FW and Thatcher WW (1977) Theory of maternal recognition of pregnancy in swine based on estrogen controlled endocrine versus exocrine secretion of prostaglandin $F_{20}$ by uterine endometrium Prostaglandins 14 397-401

Bazer FW, Clawson AJ, Robison OW and Ulberg LC (1969) Uterine capacity in gilts Jounal of Reproduction and Fertility 18 121-124

Bazer FW. Thatcher WW, Martinat-Botte $F$ and Terqui $M$ (1988a) Sexual maturation and morphological development of the reproductive tract in Large White and prolific Chinese Meishan pigs Joumal of Reproduction and Fertility 83 723-728

Bazer FW, Thatcher WW, Martinat-Botte $F$ and Terqui $M$ (I988b) Conceptus development in Large White and prolific Chinese Meishan pigs Joumal of Reproduction and Fertility $84 \quad 37-42$

Bazer FW, Thatcher WW, Martinat-Botte F, Terqui M, Lacroix MC, Bernard S, Revault $M$ and Dubois DH (1991) Composition of uterine flushings from Large White and prolific Chinese Meishan gilts Reproduction, Fertility and Development $351-60$

Bennett CL and Leymaster KA (1989) Integration of ovulation rate, potential embryonic viability and uterine capacity into a model of litter size in swine Joumal of Animal Science 67 1230-1241

Bolet G, Martinat-Botte F, Locatelli P, Gruand J, Terqui $M$ and Berthelot F (1986) Components of prolificacy in hyperprolific Large White sows compared with the Meishan and Large White breeds Gentics, Selection, Evolution 18 333-342

Bradford GE (1972) Genetic control of litter size in sheep Jounal of Reproduction and Ferfility Supplement 15 23-41

Brinkley H], Wickersham EW, First NL, and Casida LE (1964) Effect of unilateral ovariectomy on the structure and function of the corpora lutea of the pig Endocrinology 74 $462-467$
Buhi WC, Ducsay CA, Bazer FW and Roberts RM (1982) Iron transfer between the purple phosphatase uteroferrin and transferrin and its possible role in iron metabolism in the fetal pig Joumal of Biological Chemistry 257 1712-1723

Buhi WC, Ducsay CA, Bartol FF, Bazer FW and Roberts RM (1983) A function of the allantoic sac in the metabolism of uteroferrin and matemal iron by the fetal pig Placenta 4 $455-470$

Chen TT, Bazer FW, Gebhardt BM and Roberts RM (1975) Uterine secretion in mammals: synthesis and placental transport of a purple acid phosphatase in pigs Biology of Reproduction 13 304-313

Chen ZY and Dziuk PJ (1993) The influence of initial length of uterus per embryo and gestation stage on prenatal development and sex ratio in the pig Joumal of Amimal Science 71 1895-1901

Cheng P-L. (1983) A highly prolific pig breed of China - The Taihu pig. Parts I and II Pig News and Information 4 407-425

Christenson RK (1993) Ovulation rate and embryo survival in Chinese Meishan and white crossbred females joumal of Animal Science (in press)

Christenson RK, Pope CE. Zimmerman-Pope VA and Day BN (1973) Synchronization of estrus and ovulation in superovulated gilts Jounal of Animal Science $36914-918$

Christenson RK, Leymaster KA and Young LD (1987) Justification of unilateral hysterectomy-ovariectomy as a model to evaluate uterine capacity in swine Journal of Animal Science 65 738-744

Christenson RK, Young LD and Leymaster KA (1988) Postpubertal uterine horn length as affected by unilateral hysterectomy:ovariectomy (UHO) of prepuberal gilts joumal of Animal Science 66 (Supplement 1) 402 (Abstract)

Christenson RK, Bartol FF, Vallet JL, Wiley AA and Spencer TE (1992) Comparative study of uterine morphogenesis and protein secretion in neonatal Meishan (Ms) and White crossbred (Xb) pigs jounal of Animal Science 70 (Supplement 1) 264 (Abstract)

Cunningham PJ, England ME, Young LD and Zimmerman DR (1979) Selection for ovulation rate in swine: correlated response in litter size and weight Joumal of Animal Science $48509-516$

Dyck GW (1971) Ovulation rate and weight of the reproductive organs of Yorkshire and Lacombe swine Canadian Joumal of Animal Science 51 141-146

Dyck GW and Swierstra EE (1983) Growth of the reproductive tract of the gilt from birth to puberty Canadian journal of Animal Science 63 81-87

Dziuk PJ (1968) Effect of number of embryos and uterine space on embryo survival in the pig loumal of Animal Science 27 673-676

Erices $J$ and Schnurrbusch U (1979) Uterine development in swine from birth to age of eight months Archiv fur Experimentelle Veterinmedizin 33 457-473

Fenton FR, Bazer FW, Robison OW and Ulberg LC (1969) Superinduction of gilts with 7-day pig embryos Joumal of Animal Science 27144 (Abstract)

Fenton FR, Bazer FW, Robison OW and UIberg LC (1970) Effect of quantity of uterus on uterine capacity in gilts foumal of Animal Science 31 104-106

Flint APF, Saunders PTK and Ziecik AJ (1982) Blastocyst-endometrium interactions and their significance in embryonic mor. tality. In Control of Pig Reproduction pp 253-275 Ed. DJA Cole and GR Foxcroft. Butterworths, London 
Galvin JM, Day BN, Haley CS and Wilmut l (1991) Reproductive performance during early gestation in Chinese Meishan, British Large White and $\mathrm{F}_{1}$ crossbred sows joumal of Animal Science 69 (Supplement 1) 412 (Abstract)

Gama LLT and Johnson RK (1993) Changes in ovulation rate, uterine capacity, uterine dimensions, and parity effects with selection for litter size in swine foumal of Animal Science 71 608-617

Geisert RD, Thatcher WW, Roberts RM and Bazer FW (1982) Establishment of pregnancy in the pig: III. Endometrial secretory response to estradiol valerate administered on day 11 of the estrous cycle Biology of Reproduction 27 957-965

Hadek R and Getty R (1959) The changing morphology in the uterus of the growing pig American Jowmal of Veterinary Research 20 573-577

Haley CS and Lee GJ (1990) Genetic components of litter size in Meishan and Large White pigs and their crosses Proceedings of 4th World Congress on Genetics Applied to Livestock Production, Edinburgh Ed. WB Hill, R Thompson and JA Woolliams XV 458-461

Hammond J (1921) Further observations on the factors controlling fertility and foetal atrophy Joumal of Agricultural Science 11 337-366

Hancock Jl. (1958) The fertility of natural and of artificial matings in the pig Studies on Fertility 9 146-158

Hunter RHF (1966) The effect of superovulation on fertilization and embryonic survival in the pig Animal Production 8 457-465

Johnson RK, Zimmerman DR and Kittok RJ (1984) Selection for components of reproduction in swine Livestock Production Science 11 541-557

Kirby YK and Nielsen MK (1993) Altemative methods of selection for litter size in mice. III. Response to 21 generations of selection Joumal of Animal Science 71 571-578

Kirkwood RN and Aherne FX (1985) Energy intake, body composition and reproductive performance of the gilt joumal of Animal Srience 60 1518-1529

Knight JW, Bazer FW, Wallace HD and Wilcox C) (1974) Doseresponse relationships between exogenous progesterone and estradiol and porcine uterine protein secretions joumal of Animal Science $39747-751$

Knight JW, Bazer FW, Thatcher WW, Franke DE and Wallace HD (1977) Conceptus development in intact and unilaterally hysterectomized-ovariectomized gilts. Interrelations among hormonal status, placental development, fetal fluids and fetal growth jounal of Animal Science $44620-637$

Koenig JLF, Zimmerman DR. Eldridge FE and Kopf JD (1986) The effect of superovulation and selection for high ovulation rate on chromosomal abnormalities in swine ova Jourtal of Animal Science 63 (Supplement 1) 202 (Abstract)

Kunavongkrit $A$ and Larsson $K$ (1982) Ovulation rate and embryonic migration in cross-bred gilts Nordisk Veterinaermedicin 34 20-24

Legault C and Caritez JC (1983) L'expérimentation sur le porc chinois en France. I. Performances de reproduction en race pure et en croisement Genelics, Selection, Evolution 15 225-240

Leymaster KA, Christenson RK and Young LD (1986) A biological model to measure uterine potential for litter size in swine Proceedings of 3rd World Congress on Genetics Applied to Livestock Production University of Nebraska, Lincoln Ed. SE Dickerson and RK Johnson XI 209-214

Longenecker DE and Day BN (1968) Fertility level of sows superovulated at post-weaning estrus Joumal of Animal Science 27 709-711
Miyano T, Yoshikawa M, Akamatsu J, Kato S, Nanjo I and Kanda $S$ (1990a) Growth of the uterus in Meishan pigs Japanese jounal of Zootechnical Science $61742-747$

Miyano T, Akamatsu J, Kato S, Nanjo I and Kanda S (1990b) Ovarian development in Meishan pigs Theriogenology 33 769-775

Paterson AM and Lindsay DR (1980) Induction of puberty in gilts. 1. The effects of rearing conditions on reproductive performance and response to mature boars after early puberty Animal Production 31 291-297

Perry IS (1960) The incidence of embryonic mortality as a characteristic of the individual sow Joumal of Reproduction and Fertility 1 71-83

Perry JS and Rowlands IW (1962) Early pregnancy in the pig Jounul of Reproduction and Fertility 4 175-188

Pope CE. Christenson RK, Zimmerman-Pope VA and Day BN (1972) Effect of number of embryos on embryonic survival in recipient gilts Joumal of Animal Science 35 805-808

Raub TJ. Bazer FW and Roberts RM (1985) Localization of the iron transport glycoprotein, uteroferrin, in the porcine endometrium and placenta by using immunocolloidal gold Anatomical Embryology 171 253-258

Roberts RM and Bazer FW (1980) The properties, function and hormonal control of synthesis of uteroferrin, the purple protein of the pig uterus. In Steroid Induced Uterine Proteins pp 133-149 Ed. M. Beato. Elsevier/North-Holland Biomedical Press, Amsterdam

Roberts RM and Bazer FW (1988) The functions of uterine secretions Jounal of Reproduction and Fertility 82 875-892

Robertson GL, Grummer RH, Casida LE and Chapman AB (1951) Age at puberty and related phenomena in outbred $C W$ and PC gilts Joumal of Animal Science $10647-656$

Robertson HA and King GJ (1974) Plasma concentrations of progesterone, estrone, estradiol-17 $\beta$ and estrone sulphate in the pig at implantation, during pregnancy and at parturition joumal of Reproduction and Fertitity 40 133-141

Saunders PTK, Renegar RH, Raub TJ, Baumbach GA, Atkinson PH, Bazer FW and Roberts RM (1985) The carbohydrate structure of porcine uteroferrin and the role of the high mannose chains in promoting uptake by the reticuloendothelial cells of the fetal liver The Joumal of Biological Chemistry $\mathbf{2 6 0}$ 3658-3665

Scofield AM (1972) Embryonic mortality. In Pig Production pp 367-383 Ed. DJA Cole. Butterworths, London

Simmen RCM, Simmen FA, Ko $Y$ and Bazer FW (1989) Differential growth factor content of uterine luminal fluids from Large White and prolific Meishan pigs during the estrous cycle and early pregnancy Jountal of Animal Science $671538-1545$

Simmen RCM, Simmen FA and Bazer FW (1991) Regulation of synthesis of uterine secretory proteins: evidence for differential induction of porcine uteroferrin and antileukoproteinase gene expression Biology of Reproduction 44 191-200

Terqui M, Bazer FW and Martinat-Botte F (1990) Mechanisms involved in the high prolificacy of the Meishan breed. In Sympositum sur le Porc Chinois pp 19-32 Ed. M. Molenat and $C$ Legault. INRA, Toulouse

Thibault C (1959) Analyse de la fécondation de l'oeuf de la truie après accouplement ou insémination artificielle Annals of Zooteclnology 8 (Supplement) 165-177

Trout WE, McDonnell JJ, Kramer KK, Baumbach GA and Roberts RM (1991) The retinol-binding protein of the expanding pig blastocyst: molecular cloning and expression in trophectoderm and embryonic disc Molecular Endocrinology 5 1533-1540 
Trout WE, Hall JA, Stallings-Mann ML, Galvin JM, Anthony RV and Roberts RM (1992) Steroid regulation of the synthesis and secretion of retinol-binding protein by the uterus of the pig Endocrinology 130 2557-2564

Vallet JL, and Christenson RK (1993) Uterine space affects placental protein secretion in swine Biology of Reproduction . 48 575-584

Vallet JL, Christenson RK and Bartol FF (1992) Increased secretion of a retinol binding protein-like protein is temporally associated with initiation of uterine gland development in neonatal swine Jountal of Animal Science 70 (Supplement 1) 264 (Abstract)

Warnick AC, Wiggins EL, Casida LE, Grummer RH and Chapman AB (1951) Variation in puberty phenomena in inbred gilts Joumal of Animal Science $10479-493$

Webel SK and Dziuk PJ (1974) Effects of stage of gestation and uterine space on prenatal survival in the pig Jounal of Animal Science 38 960-963
Wilmut I, Ritchie WA, Haley CS, Ashworth CJ and Aitken RP (1992) A comparison of rate and uniformity of embryo development in Meishan and European white pigs joumal of Reproduction and Fertility 95 45-56

Wrathall AE (1971) Prenatal Survival in Pigs. Part 1. Ovulation Rate and its Influence on Prenatal Survival and Litter Size in Pigs. Commonwealth Agricultural Bureaux, Farnham Royal Wu MC and Dziuk PJ (1988) Ovarian influence on uterine growth in prepubertal gilts Joumal of Animal Science 66 2893-2898

Yun WL (1988) Pig breeds in China Pig News and Information 9 $407-413$

Zhang W-C, Wu JS and Rempel WE (1983) Some performance characteristics of prolific breeds of pigs in China Livestock Production Science 10 59-68 